JAROSŁAW GARA

Wydziat Nauk Pedagogicznych

Akademia Pedagogiki Specjalnej im. Marii Grzegorzewskiej

Warszawa

Forum Pedagogiczne 2018/1

Wpłynęło: 18.11 .2017

Zatwierdzono do druku: 31.03 .2018 DOI: 10.21697/fp.2018.1.09

\title{
GRANICE DYSKURSYWNOŚCI ŚWIATOPOGLĄDOWEJ WSPÓŁCZESNEJ MYŚLI PEDAGOGICZNEJ
}

\footnotetext{
„Nawarstwianie się kultury, które nadaje naszym gestom i słowom oczywiste wspólne tło, musiało uprzednio być szeregiem dokonań spełnionych przez te same gesty i słowa; i wystarczy lekkie zmęczenie, by przerwać tę najgłębszą łączność".
}

(Merleau-Ponty 1976a, s. 73 )

Streszczenie: Punktem odniesienia dla tytułowego problemu są trzy nierozłączne idee, określające kondycję współczesności oraz przynależną jej praxis. Umownie można je określić mianem etosów polisemiczności i pluralizmu kulturowego, demokracji i transparentności społecznej, a także praw człowieka i upodmiotowienia statusu jednostki. Owe etosy, zgodnie z przyjętym punktem widzenia, określają nieprzekraczalne granice myśli pedagogicznej, która pretenduje do tego, aby być myślą współczesną. Dookreślanie myśli jako współczesnej z punktu widzenia granic jej dyskursywności światopoglądowej wymaga odróżnienia dwóch podstawowych sposobów rozumienia tego, co współczesne. W tym też kontekście ujęta została swoistość myśli pedagogicznej, traktowanej jako jedna z perspektyw poznawczych pedagogiki ogólnej oraz sformułowane zostały formalne kryteria oceny wartości naukowej współczesnej myśli pedagogicznej.

Słowa kluczowe: pedagogika teoretyczna, pedagogika ogólna, myśl pedagogiczna, analiza fenomenologiczna, polisemiczność epistemologiczno-metodologiczna.

\section{Wprowadzenie do przedmiotowego pola analizy}

Zasadnicza teza, przyjęta w kontekście tytułowego problemu, o którym będzie jeszcze mowa, wydawać się może tyleż oczywista, co i prosta, niemniej usytuowana zostaje ona w kontekstach problemowych oraz towarzyszących im 
argumentatywnych racjach dowodzenia, które za tak oczywiste uznane już być nie mogą ${ }^{1}$ W tym też względzie wprowadzam istotne dystynkcje dla niniejszego rozumowania oraz artykułowanych $\mathrm{w}$ jego obrębie przesłanek ${ }^{2}$. Z kolei samo

1 Struktura wywodu niniejszego artykułu w swym całościowym zamyśle i postaci obejmuje problematyzację następujących zagadnień: 1) heurystyczne określenie problemu granic dyskursywności światopoglądowej współczesnej myśli pedagogicznej; 2) heurystyczne dookreślenie pojęć „granica” i „współczesna myśl” pedagogiczna; 3) dookreślenie kategorii myśli pedagogicznej jako optyki dyskursu pedagogiki ogólnej; 4) dookreślenie dyscyplinarnej swoistość formacji intelektualnej myśli pedagogicznej; 5) dookreślenie casusu dwupodmiotowości myśli pedagogicznej jako antropologii praktycznej; 6) dookreślenie historyczno-kulturowo-społeczno-pokoleniowego zapośredniczenia oraz światopoglądowości myśli pedagogicznej; 7) dookreślenie przesądów implikowanych światopoglądową totalnością myślenia i działania pedagogicznego; 8) dookreślenie racjonalności roszczenia totalności w kontekście uprawomocnień polisemiczności epistemologiczno-metodologicznej myśli pedagogicznej; 9) dookreślenie kryterialności orzekania o granicach dyskursywności światopoglądowej współczesnej myśli pedagogicznej. W takim problemowym ustrukturyzowaniu artykuł ten stanowi pierwotną całość i tylko w takiej postaci w pełni odzwierciedla on koncepcyjny i argumentatywny zamysł autorski. W tym miejscu, ze względu na limity objętościowe i przyjęte zasady redakcji niniejszego przedsięwzięcia wydawniczego, publikowany jest tylko selektywny wybór powyższych zagadnień, które w sposób integralny składają się na problematyzację ty tułowego zagadnienia. Poza wprowadzeniem do przedmiotowego pola analizy, z pewnymi przeformułowaniami lub dopowiedzeniami, prezentuję tu zatem selektywny wybór zagadnień: 1, 2, 3, 4, 8 i 9. Z tego też względu artykuł ten w swej pełnej postaci i jednobrzmiącej formule tytułu złożony został do druku również w innym miejscu (zob. Gara 2018, s. 1-34).

2 Niniejsza problematyzacja nie ma charakteru systematycznego przeglądu określonych stanowisk na gruncie pedagogiki, nie znany jest mi bowiem taki lub przynajmniej zbliżony sposób wyodrębnienia i ujęcia związanego z tym przedmiotem zainteresowania. Zarówno sam sposób dookreślania poszczególnych problemów, jak i ich związków z innymi problemami formułowany jest tu w nastawieniu in abstracto i ma charakter pierwszoosobowego namysłu/oglądu tytułowego zagadnienia. W zdecydowanej mierze tekst poświęcony jest zatem autorskiemu ujęciu i rozumieniu tak wyodrębnianego przedmiotu zainteresowania. W warstwie zasadniczych założeń, które czynię punktem swojego odniesienia, podążam więc własną drogą rozumowania na rzecz sformułowania przyczynków dla tak ujmowanego problemu. W tym też względzie daję sobie prawo, aby poddać autonomicznemu przemyśleniu tytułowe zagadnienie, zgodnie z własnymi punktami widzenia i własną optyką poznania, jak również własną metodą dochodzenia określonych racji, nawiązującą do fenomenologicznej analizy refleksyjnej. Wychodzę zatem nie tylko od swoistych punktów poznawczego oparcia, lecz także od tego, co jest jeszcze bardziej prymarne $\mathrm{w}$ tej sytuacji, mianowicie, od uznania samego prawa do mówienia we własnym imieniu oraz własnym językiem - z głębi własnych specyficznych sposobów rozumowania i dowodzenia oraz w kontekście własnych przebytych dróg i zasobów doświadczenia jako podmiot, który przedmiotem swoich dyskursywnych odniesień i zainteresowań w ogólności czyni współczesną myśl pedagogiczną. „Wypowiadanie siebie” - swojego konceptu, swoich punktów widzenia, dowodzonych racji i uznawanych pryncypiów jest zaś tym, co wydobywa źródłowy rys etosu autorstwa (łac. auctor - „świadek, sprawca, twórca”). A dla doświadczenia, jak i samej ekspresji podmiotowego wymiaru autorstwa zawsze istnieje tylko jedno autentyczne, choć zawsze subiektywne i ważkie egzystencjalnie usprawiedliwienie, które wszak nie każdego może satysfakcjonować. No ale to już inna sprawa: „Ja jestem mną i moimi okolicznościami i jeśli nie uda mi się ich ocalić, to nie ocalę 
przedmiotowe pole zainteresowania pedagogiki ogólnej rozpatruję tu, zgodnie z tytułową formułą, przez pryzmat kategorii myśli pedagogicznej.

Jednym z podstawowych aksjomatów, który czynię punktem odniesienia swoich analiz, jest to, że aktualność i adekwatność określonej myśli, która ukazuje się - jak w ogólności powiedziałby to Maurice Merleau-Ponty - „we własnym horyzoncie historycznym” (Merleau-Ponty 1976b, s. 231; por. także: Barbaras, 2001, s. 26-27) nie tylko musi być ściśle skorelowana $\mathrm{z}$ odnoszeniem się do szeroko rozumianych realiów i zjawisk otaczającego świata, lecz także musi uwzględniać, respektować lub czynić ramami swoich skonkretyzowanych reprezentacji światopoglądowych oraz towarzyszących im projektów dziejowe zdobycze i stabilizujące osiągnięcia, mierzone w skali procesów i przemian historycznych, kulturowych, społecznych czy pokoleniowych. Określone reprezentacje poznawcze myśli pedagogicznej, które nie odnotowują tej faktyczności doświadczenia współczesnego człowieka oraz świata ludzkich spraw lub w ogóle nie przyjmują tego do wiadomości, kreśląc w tym względzie swoje ahistoryczne światopoglądowo projekty (tzn. takie, które są oparte na roszczeniu, zgodnie z którym określonym faktom lub zjawiskom nadawane są znaczenia w oderwaniu od określonych uwarunkowań rozwoju historycznego), same stawiają się więc poza własnym, immanentnym kontekstem doświadczenia współczesności ${ }^{4}$.

Bez wątpienia do takich dziejowych zdoboczy i stabilizujących osiągnięć, które określają poczucie godności, sposób życia oraz formy partycypacji współczesnego człowieka cywilizacji zachodniej, należy to, co umownie można określić mianem: 1) etosu polisemiczności i pluralizmu kulturowego; 2) etosu demokratyzacji i transparentności społecznej oraz 3) etosu praw człowieka i upodmiotowienia statusu jednostki. Oczywiście, pomijam w tym miejscu kwestię dyskusyjności,

i siebie” (Ortega y Gasset 2008, s. 22). Mając więc tego świadomość, pozostawiam Czytelnikowi pełne prawo do własnych ocen zasadności owych punktów widzenia i sposobów dowodzenia po przebyciu myślowej drogi, którą pozwalam sobie tu poddać namysłowi. A nie jest to wszak droga ostateczna, bezwzględna i pozbawiona dylematów, ponieważ z założenia ma ona charakter problematyzacji. Jest to też problematyzacja, ze względu na limity objętościowe, wybiórcza i ograniczona, i należy mieć tego pełną świadomość, przystępując do lektury tego tekstu.

3 Założenie to można zestawić z czterema podstawowymi egzystencjaliami (wolnością, językowością, historycznością i cielesnością) w fenomenologicznym projekcie kategorii pedagogicznych Eugena Finka, gdzie kategorię historyczności i historycznego factum odnieść należy do wyróżnionych przez Dietricha Dennera koegzystencjalnych form ludzkiej praxis (ekonomia, etyka, pedagogika, polityka, sztuka i religia), a w tym kontekście problemowym w szczególności do tego, co właśnie wyraża się w myśleniu i działaniu pedagogicznym (por. Benner, 2015, s. 27, 13-14).

4 Jednym z wyrazistych przykładów takiego ahistorycznego projektu i towarzyszących mu nastawień poznawczych jest dla mnie próba wskrzeszania kategorii arete w jej średniowieczno-religijnych konkretyzacjach/znaczeniach i zastosowaniach, w odniesieniu do aksjologicznych wymiarów postulowanej praxis kulturowej, społecznej i edukacyjnej (zob. K. Śleziński 2016, s. 93). 
niejednoznaczności lub płynności określonych praktyk, które w różnej postaci oraz w rożnym zakresie wpisują się racjonalność owych etosów. Tak czy inaczej zawsze, w moim przekonaniu, są one wyrazem afirmacji idei symetryczności oraz równoważenia się podmiotowych praw na linii: Ja (swojskość/tożsamość) - Ty (inność/ różnica). Z każdym z tych etosów związane są również określone kwestie, odnoszone do poszczególnych obszarów praxis kulturowej, społecznej czy edukacyjnej ${ }^{5}$, tj. w pierwszym przypadku - dywergencyjność, generatywność, transgresyjność, w drugim przypadku - praworządność, samorządność, partycypacja, a w trzecim przypadku - emancypacja, samorealizacja czy antycypacja ${ }^{6}$.

Kwestie te ujmuję w kategoriach specyficznych dla współczesności procesów, zjawisk i tendencji, które odgrywają istotną rolę w różnych obszarach praxis kulturowej, społecznej czy edukacyjnej. Przywołuję je również w ich podstawowych znaczeniach dla uwyraźnienia owych procesów, zjawisk i tendencji jako istotnych przesłanek w określaniu tego, co współczesne. Oczywiście, nie sposób w pełni rozwinąć tej myśli w tym miejscu. Dla potrzeb tego wywodu pozwolę sobie więc stwierdzić, że kwestie te utożsamiam z uznaniem/dowartościowaniem roli i znaczenia w różnych obszarach praxis kulturowej, społecznej czy edukacyjnej: 1) doświadczenia rozbieżności - w przypadku dywergencyjności; powoływania do życia tego, co nowe - w przypadku generatywności; przekraczania limitów i zastanych ograniczeń - w przypadku transgresyjności (etos polisemiczności i pluralizmu kulturowego); 2) uznania zasad równości wobec prawa i jego obowiązywalności - w przypadku praworządności; dowartościowania oddolnych społecznościowych inicjatyw - w przypadku samorządności; powstawania nowych form współuczestnictwa i aktywizmu - w przypadku partycypacji (etos demokratyzacji i transparentności społecznej); 3) uzyskiwania/potwierdzania/wywalczania własnego podmiotowego statusu - w przypadku emancypacji; uznania prawa do samourzeczywistniania - w przypadku samorealizacji; odpowiedzialności za projektowanie własnej przyszłości - w przypadku antycypacji (etos praw człowieka i upodmiotowienia statusu jednostki). Wszystkie te kategorie, w odniesieniu do określonych etosów i we wskazanych zakresach znaczeniowych, konstruktywnie rzecz ujmując, traktuję jako wzajemnie się warunkujące i równoważące, a zatem

5 W sposób pośredni nawiązuję tu do formuły „podstawowej struktury myślenia i działania pedagogicznego" Dietricha Bennera, ale właśnie z punktu widzenia owej historyczno-kulturowo-społeczno-pokoleniowej praxis, dostępnej w intersubiektywnym doświadczeniu sobie współczesnych autorów (por. Benner 2015, s. 11-16), którzy w tej samej mierze określani są horyzontem świata życia codziennego wraz przynależnymi mu kodami, rytuałami, rytami i standardami (zob. Goffman 2008).

$6 \mathrm{Z}$ tak problematyzowanym zagadnieniem skorelować można również wyróżniane przez Józefa Górniewicza kategorie pedagogiczne (Górniewicz 2001). Faktyczną afirmację tychże kategorii w myśli pedagogicznej, która dookreśla horyzonty dla projektów pedagogicznych i formacji pedagogicznej, w ogólności należy bowiem wiązać z rzeczywistą afirmacją wyróżnionych tu etosów. 
zakładam, że powinny one stanowić dla siebie nawzajem zarówno przesłankę wzmacniającą (wspierającą), jak i przesłankę ograniczająca (limitującą).

W tym też kontekście sformułować można przewodnią tezę, zgodnie z którą myśl pedagogiczna niewykazująca się respektem dla przywoływanych etosów lub kreśląca swe własne projekty, dokonując ich marginalizacji lub wręcz je dezawuując, przestaje być reprezentatywna, aby tak rzec, dla historiozoficznego statusu współczesności. W takim znaczeniu rozumiem też tytułowe granice dyskursywności światopoglądowej myśli pedagogicznej, która jest myślą na miarę współczesności. Rozumowanie lub logiczne wyprowadzanie wniosków i implikacji z określonych doktryn lub reprezentacji światopoglądowych myśli pedagogicznej w ogólności nie może zatem naruszać tych dziejowo i intersubiektywnie ukonstytuowanych granic respektu oraz uznania dla zasad pluralizacji przestrzeni kulturowej (implikującej uznanie wartości polisemiczności), demokratyzacji przestrzeni społecznej (implikującej uznanie wartości transparentności) oraz upodmiotowienia przestrzeni relacji interpersonalnych (implikującego uznanie praw człowieka). Oczywiście ma to miejsce wówczas, gdy tylko myśl określana jest emancypacyjnymi miarami i pryncypiami współczesności oraz przejściem od ortodoksji do heterodoksji. I choć wśród współczesnych czołowych polskich pedagogów uniwersyteckich okresu potransformacyjnego kwestie te nie budzą wątpliwości, to jednak, śledząc literaturę przedmiotu, można odnotować również i takie tendencje, zgodnie z którymi implicite lub explicite wartości stojące u podstaw wskazanych etosów w mniejszym lub większym stopniu podlegają światopoglądowej deprecjacji lub degradacji, co znajduje też odzwierciedlenie w sposobie ujmowania i rozpatrywania różnych problemów, określających przedmiotowe pole zainteresowania pedagogiki ogólnej oraz samej myśli pedagogicznej.

\section{Heurystyczne dookreślenie pojęcia „granica” i „współczesna myśl”}

Ujmując rzecz historiozoficznie, należy stwierdzić, że zawsze istnieją jakieś względnie jednoznaczne i intersubiektywnie podzielane lub oczekiwane granice, określające warunki i gwarancje, które fundują nasz status i możliwości działania w określonym czasie i miejscu. Granice na miarę świata, który jest naszym własnym światem, ponieważ określa i warunkuje hic et nunc nasze egzystencjalne doświadczenie i swoistość naszej świadomości historyczno-kulturowo-społeczno-pokoleniowej. W takim też znaczeniu będę odnosił się do problemu granic dyskursywności światopoglądowej współczesnej myśli pedagogicznej. Owe granice rozważam więc z punktu widzenia doświadczenia i świadomości historycznej, kulturowej, społecznej czy pokoleniowej współczesnego człowieka Zachodu. Co więcej, granice, o których będzie tu mowa, paradoksalnie, mogą lub są zazwyczaj naruszane/nadwątlane w nastawieniu, domeną którego jest właśnie bezkrytyczne - ahistoryczne, 
ideologiczne, dogmatyczne lub fundamentalistyczne ${ }^{7}$ przeświadczenie o istnieniu instancji określonych granic, jako sposobu zabezpieczania i podtrzymywania trwałości wykoncypowanego jako jedynie prawowiernego i prawdziwego lub ideowo wyobrażonego i upragnionego świata ludzkich spraw. Zgodnie z takim epistemologiczno-normatywnym nastawieniem reprezentacje te traktowane są jako jedynie uprawnione i uznawane postacie oczekiwanego światopoglądu, pozbawionego skazy herezji i błędu nieortodoksji. Zawsze w sposób oczywisty same uznają one i proklamują siebie za w pełni ponadczasowe, uniwersalne i niedyskursywne w zetknięciu czy konfrontacji z innymi reprezentacjami światopoglądowymi.

Przymiotnikowe określenie tego, co „współczesne”, jak również „współczesnej” myśli pedagogicznej - ze względu na jej szczególny, projektujący i aplikacyjny charakter w odniesieniu do historyczno-kulturowo-społeczno-pokoleniowej praxis - może być, jak się wydaje, dookreślane i rozpatrywane w dwóch podstawowych znaczeniach.

Pierwsze znaczenie, utrwalone w środowiskowym obiegu klasyfikacyjnym, ujmowane jest przez pryzmat definicji, które można określić mianem empirycznych $i$ historiograficznych. Mówimy tu zatem o porządkującym podejściu odnotowywania, wypunktowywania i wyliczania wszystkich tych nurtów myśli pedagogicznej, które zgodnie z kryterium temporalnym są tworzone, rozwijane i reprezentowane $\mathrm{w}$ umownie dookreślanym przedziale czasu. Tym samym bierzemy pod uwagę ogół reprezentacji myśli pedagogicznej o formalnie dookreślonej przynależności historycznej. Można zatem przyjąć, że logika typologizowania określana jest tu rozstrzygnięciami zgodnymi z kryterium temporalno-ilościowym, we właściwym sobie znaczeniu.

Drugie znaczenie, istotne z punktu widzenia podejmowanego tu problemu granic dyskursywności światopoglądowej, można ujmować przez pryzmat definicji, które formułowane są $\mathrm{w}$ nastawieniu ejdetycznym $i$ historiozoficznym. Zgodnie z tą optyką klasyfikacyjną, mówiąc o współczesnej myśli pedagogicznej, bierzemy pod uwagę te jej konkretyzacje, które są reprezentatywne dla ducha czasów oraz odzwierciedlają historyczne, kulturowe, społeczne czy pokoleniowe, a zatem intersubiektywnie ukonstytuowane tendencje współczesności, które określają granice światopoglądowości. Problem tego, co współczesne, rozpatrujemy tu zatem w kontekście rozważań nad procesami dziejowymi, które doprowadziły do ukształtowania się prawidłowości, tendencji i standardów czasów, w których żyjemy. Co więcej, określenie tego, co współczesne, oznacza, że myśl taka odnosi się do wszystkich przewodnich tendencji, problemów i wyzwań czasów sobie współczesnych, podejmując zarazem próbę redefiniowania kondycji współczesnego człowieka oraz projektowania adekwatnych/przystających do ducha tychże czasów rozstrzygnięć, które w sposób aktualny antycypują procesy jego socjalizacji, przystosowania,

7 Każde z tych nastawień jest dla mnie reprezentacją zarówno przeświadczeń poznawczych, jak i odniesień do otaczającego świata, których wspólną cechą jest totalność myślenia i działania. 
inkulturacji, wychowania, kształcenia czy w ogóle rozwoju. Można zatem przyjąć, że w tym podejściu logika typologizowania określana jest rozstrzygnięciami, zgodnymi z kryterium temporalno-jakościowym, w swoistym tego słowa znaczeniu.

\section{Kategoria myśli pedagogicznej jako optyka dyskursu pedagogiki ogólnej}

Współczesna pedagogika ogólna ${ }^{8}$, zgodnie z ujęciem Teresy Hejnickiej-Bezwińskiej, może obejmować co najmniej kilka podstawowych perspektyw czy też optyk dookreślania swojego przedmiotu zainteresowania - obszarów eksploracji oraz powiązanych z tym specyficznych nastawień poznawczych ${ }^{9}$. Pośród tych różnych perspektyw - zdaniem Romana Schulza - jedną z tych optyk, którym w uprawianiu pedagogiki ogólnej należy przypisać szczególne miejsce, jest też myśl pedagogiczna, ponieważ „pedagogika ogólna to w głównej mierze teren uprawiania myśli pedagogicznej, odnoszącej się do świata edukacyjnego jako całości” (Schulz 2016, s. 30) ${ }^{10}$. Owa myśl, co należy podkreślić i na co zwraca również uwagę Bogusław Śliwerski, genetycznie wyrasta ze źródeł szeroko rozumianej humanistyki oraz w sposób nieredukowalny pozostaje $\mathrm{z}$ nią $\mathrm{w}$ tak czy inaczej dookreślanej relacji i sprzężeniu zwrotnym (Śliwerski 2009, s. 43; por. Wojnar 2000, s. 136-146).

8 Pedagogika ogólna oraz przyjęte względem niej porządkujące ujęcia, które w swych zasadniczych rozróżnieniach nawiązują do stanowiska Romana Schulza, pojawiają się w tej pracy jako tematycznie, konsekwentnie usytuowane w merytorycznej formule przedsięwzięcia naukowego, zorganizowanego pod tytułem Polskie koncepcje pedagogiki ogólnej w ujęciu porównawczym we Wrocławiu, 27-28 września 2017 roku. W tym znaczeniu wyłożony przez Romana Schulza Zarys pedagogiki ogólnej wraz z wyeksponowaniem przynależnego jej elementu światopoglądowego traktuję jako istotną przesłankę dla uprawomocnień osadzenia swoich analiz oraz towarzyszącego im zamysłu koncepcyjnego $\mathrm{w}$ dorobku polskich koncepcji pedagogiki ogólnej. $Z$ tego punktu widzenia nie sposób oddzielić od siebie podjętych w tym miejscu zagadnień, w ich specyficznie dookreślanych znaczeniach: 1) heurystycznie rozumianych granic dyskursywności światopoglądowej oraz 2) odnoszonej do przedmiotowego pola zainteresowania pedagogiki ogólnej samej kategorii myśli pedagogicznej.

9 Teresa Hejnicka-Bezwińska w swym definicyjnym dookreśleniu wyróżnia następujące kompleksy tematyczne, które określają przedmiot zainteresowania pedagogii ogólnej: „a) współczesne kierunki i ideologie pedagogiczne; b) filozofia edukacji; c) aksjologia wychowania; d) metodologia badań nad procesami edukacyjnymi i dyskursami edukacyjnymi; e) ontyczne podstawy edukacji i jej funkcje społeczne; f) język pedagogiki («pulsujące kategorie pojęciowe»); g) tożsamość pedagogiki w procesie przechodzenia od ortodoksji do heterogeniczności; h) metateoria pedagogiki (ewolucja ogólności w pedagogicznym myśleniu o edukacji); i) relacje pomiędzy wiedzą pedagogiczną a praktyką edukacyjną; j) miejsce pedagogiki w kontekście przemian edukacyjnych" (Hejnicka-Bezwińska 2008, s. 496).

10 Trzy pierwsze rozdziały tejże pracy (Pedagogika, myśl pedagogiczna, pedagogika ogólna, O kategorii ogólności w pedagogice ogólnej oraz Czy pedagogika ma swoje „wielkie pytania?”) są nie do przecenienia z punktu widzenia teoretycznej, ale i syntetycznej systematyzacji i uporządkowania różnych zagadnień, związanych z przedmiotem zainteresowania pedagogiki ogólnej. 
Zgodnie z porządkującym ujęciem autora Szkiców z pedagogiki ogólnej za nadrzędną kategorię w rozważaniu dyscyplinarnej tożsamości pedagogiki ogólnej należy uznać pedagogikę teoretyczną, którą z założenia należy dookreślać jako „składową umysłową kultury symbolicznej”, a co za tym idzie, reprezentację dyskursu edukacyjnego, który „zasadniczo posługuje się teoretycznymi systemami symbolicznymi". Twórców lub przedstawicieli pedagogiki teoretycznej, zgodnie z tym podejściem, należy zaś postrzegać jako „zawodowych intelektualistów”, zdolnych do „zdyscyplinowanej pracy umysłowej” (Schulz 2016, s. 15) ${ }^{11}$. Jednym z nieredukowalnych aspektów pedagogiki teoretycznej jest też dyskurs światopoglądowy, który zgodnie z tym ujęciem, odnoszony jest do trzech podstawowych obszarów problemowych: „ontologii wychowania, aksjologii wychowania oraz epistemologii pedagogiki" (Schulz 2016, s. 17). W tym znaczeniu dyskurs edukacyjny w mniejszym lub większym stopniu zawsze dotyczy również podstaw światopoglądowych (Schulz 2016, s. 20). Celem pedagogiki teoretycznej jest „przekształcanie jednostkowych doświadczeń edukacyjnych w wiedzę ogólną”, „racjonalizacja pedagogicznego doświadczenia” oraz „racjonalne porządkowanie” składowych wiedzy ogólnej. Efekty pedagogiki teoretycznej wyrażane są w „złożonych wypowiedziach”, takich jak: „ideologie pedagogiczne, doktryny pedagogiczne, koncepcje filozoficzne, teorie pedagogiczne, teorie naukowe itp." (Schulz 2016, s. 15). Sama pedagogika ogólna, zgodnie z kryterium przedmiotowym, jest traktowana w tej relacji jako jeden z trzech podstawowych działów - obok subdyscyplin ogólnopedagogicznych (np. historii wychowania) i subdyscyplin szczegółowych (np. pedagogiki specjalnej) - pedagogiki teoretycznej (Schulz 2016, s. 16-17). Z kolei przyjmując kryterium określonych „operacji intelektualnych” (metod i nastawień pracy umysłowej) stosowanych w pedagogice teoretycznej, należy wyróżnić w tym względzie trzy podstawowe optyki: „myśl pedagogiczną”, „pedagogikę prakseologiczną” i „pedagogikę scjentystyczną” (Schulz 2016, s. 17-18). W końcu, wskazując na podstawowe własności i charakter samej myśli pedagogicznej, należy powiedzieć, że wyraża się ona w „formułowaniu oraz rozstrzyganiu pytań światopoglądowych dotyczących edukacji” (Schulz 2016, s. 17). Z tego też względu myśl pedagogiczna

11 Odwołuję się w tym miejscu do wszystkich tych autorskich ustaleń Romana Schulza nie jako ostatecznych i niedyskursywnych, gdyż i sam autor tak ich nie traktuje. Nawiązania te traktuję jako egzemplifikację jednej z konkretnych koncepcyjnych prób poddania namysłowi kwestii stosunków i zależności pomiędzy zakresami znaczeniowymi takich kategorii, jak: pedagogika teoretyczna - pedagogika ogólna - myśl pedagogiczna - światopoglądowość myśli pedagogicznej. Oczywiście, nie wyklucza to również w żadnej mierze odwoływania się do innych tego typu prób systematyzacji lub krytycznego namysłu nad ich kompletnością. Z punktu widzenia zasadniczego przedmiotu zainteresowania niniejszego artykułu i towarzyszących mu celów nie jest to jednak miejsce, w którym podjęcie takiej dyskusji byłoby czymś zasadnym. Choć sam fakt odwołania się do tego typu prób ustalania stosunków i zależności pomiędzy owymi zakresami znaczeniowymi wyróżnionych tu kategorii można traktować jako poznawcze uprawomocnienie do podjęcia tytułowego zagadnienia w ramach współczesnego dyskursu pedagogicznego. 
jako ta, która koncentruje się na „formułowaniu ideowych założeń, podstaw światopoglądowych (ontologicznych, aksjologicznych i epistemologicznych)", może być również określana mianem „pedagogiki światopoglądowej”. Obok tego określenia w sposób synonimiczny możemy też, rozkładając na różne sposoby akcenty epistemologiczne i metodologiczne z tym związane, posługiwać się takimi formułami, jak: „,filozofia wychowania”, „pedagogika filozoficzna”, „pedagogika ideologiczna”, „pedagogika ideałów” itp. Samych przedstawicieli myśli pedagogicznej, zdaniem Romana Schulza, należy zaś traktować jako twórców i propagatorów idei, ideologii i doktryn pedagogicznych (Schulz 2016, s. 21).

Ostatnia z ważnych własności myśli pedagogicznej - zgodnie z tym dookreśleniem - wyraża się zaś w tym, że nie jest ona bezpośrednio zaprzęgnięta w realizację bieżących i konkretnych zadań praktyki wychowania i kształcenia. Nie na tym też polega jej zasadnicza optyka jako reprezentacji uogólnionego i teoretycznego dyskursu edukacyjnego, ponieważ przede wszystkim ma ona za zadanie wydobywać, uwyraźniać, określać, redefiniować lub na nowo wytyczać perspektywiczny (strategiczny, dalekosiężny, długodystansowy) horyzont myślenia i działania pedagogicznego (Schulz 2016, s. 23). Teleologiczny horyzont oraz sens i znaczenie samego działania są tu określane lub uwyraźniane w obrębie projektu myśli pedagogicznej, która obejmuje swym namysłem to, co wykracza poza doraźnie i akcydentalnie definiowane uwarunkowania, presje, potrzeby i interesy praktyki pedagogicznej. Działanie samo z siebie, z założenia, nie jest bowiem w stanie antycypować teleologicznego horyzontu przedsiębranych oddziaływań, ani też jego sensów, ujmowanych w swej prospektywności i perspektywiczności. Dlatego też zawsze, w większym lub mniejszym stopniu, uzasadnienia tego horyzontu wyprowadzane są z dookreślanej w jakiś sposób podstawy, która funduje ową prospektywność i perspektywiczność oraz towarzyszące temu racje i przesłanki światopoglądowe. Temu też służy i taką funkcję spełnia w swej teoretyczności i ogólności myśl pedagogiczna.

\section{Dyscyplinarna swoistość formacji intelektualnej myśli pedagogicznej}

Odwołując się zatem do kategorii myśli pedagogicznej, należy również podkreślić jej swoistość/osobliwość ${ }^{12} \mathrm{~W}$ zestawieniu $\mathrm{z}$ analogicznymi formacjami/konstruktami intelektualnymi, tj. myślą filozoficzną, myślą historyczną, myślą socjologiczną,

12 Warto podkreślić w tym miejscu, że podejmowanie zagadnienia dyscyplinarnej swoistości czy też tożsamości myśli pedagogicznej, zgodnie z moim podejściem, w żadnej mierze nie przeczy zasadności odwoływania się do epistemologiczno-metodologicznych idei interdyscyplinarności lub transdycyplinarności. Myśl pedagogiczna, niezależnie od tego, w jakim nastawieniu epistemologiczno-metodologicznym nie byłaby uprawiana, musi bowiem odznaczać się swoją dyscyplinarną tożsamością. W innym przypadku nie ma bowiem w ogóle potrzeby posługiwania się taką formułą, jak „myśl pedagogiczna”, ponieważ w pełni wystarczająca staje się wtedy sama formuła „myśl”. Oczywiście, osobiście stoję na stanowisku, że myśl pedagogiczna, ujmowana zarówno in abstracto, jak i in concreto, posiada swoje specyficzne rysy i swoją dyscyplinarną 
myślą psychologiczną czy nawet myślą teologiczną. Poza wspólnymi, formalnymi funkcjami myśli humanistycznej i społecznej (np. funkcja identyfikacyjna, orientacyjna, diagnostyczno-ewaluacyjna, regulacyjna), na co również zwraca uwagę Roman Schulz (2016, s. 23), można bowiem wskazać na pewne specyficzne własności, które w rozpatrywaniu myśli pedagogicznej czynią niezbędnym uwzględnianie jej własnej tożsamości oraz związanej z tym nieredukowalnej swoistości/osobliwości.

Można zatem powiedzieć, jak się wydaje, że każda z tych sprofilowanych dyscyplinarnie formacji intelektualnych (a zatem filozoficznie, historycznie, socjologicznie, psychologicznie, czy teologicznie) może być bowiem uprawiana sama dla siebie i w obrębie samej siebie, bez konieczności wieloaspektowego, wielopłaszczyznowego czy wielodziedzinowego wykraczania ku konkretnemu człowiekowi w trajektoriach jego zindywidualizowanych (podmiotowo, społecznie, kulturowo) losów urzeczywistniania miary siebie samego. Nie stanowi to zatem ich immanentnego i nieredukowalnego celu samego intelektualnego ruchu myśli, jej egzystencjalnej powagi i deontologicznych zobowiązań. Każda z tych myśli, wyrażona w dyscyplinarnie dookreślonej formacji intelektualnej, potwierdza więc swą powagę i zobowiązania już poprzez sam fakt eksploracyjno-eksplanacyjnego sięgania (odkrywania, wyjaśnienia, porządkowania, tematyzowania) poznawczego obiektu swojego zainteresowania. Żadna z tych myśli dla zachowania swojej tożsamości nie musi, choć oczywiście zawsze może, być powodowana konstytutywnym imperatywem urzeczywistniania dobra przystosowawczego i rozwojowego człowieka $^{13}$, rozpatrywanego w jego wszechstronnych kontekstach/aspektach (podmiotowych, społecznych, kulturowych). Zarazem każda z tych myśli może spełniać się i potwierdzać miarę swej naukowej wagi i doniosłości w samej kognitywnej pasji lub określonym interesie poznania przedmiotowego pola badań - w racjonalnym obejmowaniu swojego obiektu jako poznawczego problematu, poddanego oglądowi, namysłowi, racjonalizacji i uprzedmiotowiającej tematyzacji.

Z myślą pedagogiczną jest jednak inaczej. Zawsze bowiem ostatecznie potwierdza ona swą dyscyplinarną tożsamość w intencji, która musi brać pod uwagę wymiar apliacyjno-projektujący, odniesiony do biegu życia i trajektorii losu konkretnego człowieka, w jego przystosowaniu i rozwoju oraz związanych z tym zagrożeń lub możliwości, wyzwań lub konieczności. W ten sposób myśl pedagogiczna potwierdza swą dyscyplinarną tożsamość poprzez koncentrowanie się na

tożsamość. Mam jednak świadomość, że można również podchodzić do tej kwestii inaczej, i oczywiście nikomu nie odbieram do tego prawa.

13 W tym kontekście problemowym kategorie dobra przystosowawczego i rozwojowego traktuję jako równoważące się siły, które do pewnego stopnia i w pewnych względach mają charakter opozycyjny. W tym znaczeniu pojęcie „dobra przystosowawczego” łączę ze społeczno-kulturowymi procesami adaptacji (umiejętności dostosowania się i funkcjonowania w kontekście istniejących układów odniesień), a pojęcie „dobra rozwojowego” - ze społeczno-kulturowymi procesami emancypacji (umiejętności dążenia do autonomii i zdobywania podmiotowej pozycji i znaczenia wbrew zastanym układom odniesień). 
szeroko rozumianym dobru przystosowawczym i rozwojowym człowieka, choć oczywiście sama kategoria dobra, ze względu na swe specyficzne konteksty kulturowe, społeczne i pokoleniowe, może być tu różnie dookreślana i rozumiana. Konstytutywnym i nieredukowalnym wzorcem tożsamości myśli pedagogicznej jest zatem afirmacja dobra człowieka jako podmiotu, a co za tym idzie, nie poprzestawanie „na” jego uprzedmiatawiającej tematyzacji, jako wyłącznie przedmiotu (obiektu) zracjonalizowanych i systematycznych form poznania.

\section{Racjonalność roszczenia totalności versus uprawomocnienia polisemiczności epistemologiczno-metodologicznej myśli pedagogicznej}

Przywołane etosy kulturowej, społecznej i edukacyjnej praxis (tzn. pluralizacji, demokratyzacji i upodmiotowienia), które są tu ujmowane jako dziejowe zdobycze i stabilizujące rudymenty kondycji współczesnego świata Zachodu, nie tylko utorowały drogę do naukowej legitymizacji polisemiczności epistemologiczno-metodologicznej i równouprawnienia różnych dyskursów światopoglądowych, lecz także poddały w wątpliwość logikę konstatowania ostatecznych i niedyskursywnych rozstrzygnięć ${ }^{14}$. Domeną tego, co współczesne, jest bowiem nieustanne ponawianie pytania o miary i kryteria swej własnej aktualności i adekwatności, a co za tym idzie, stawianie pytań o swe własne uprawomocnienia w obliczu tendencji, wyzwań i procesów zachodzących w otaczającym człowieka świecie. $Z$ tego też względu żadne z paradygmatycznych lub światopoglądowych podejść nie dysponuje legitymizacją do strukturalnego (administracyjnego) lub symbolicznego (opiniotwórczego) zawłaszczenia, kolonizacji lub monopolizacji (totalności) dyskursu pedagogicznego - narzucania mu swych własnych matryc poznawczych czy aksjologicznych jako czegoś oczywistego i niedyskursywnego, urastającego do rangi raz na zawsze określonych aksjomatów. Takie aksjomaty, z naukowego punktu widzenia, nieustannie poddawane są aktualizacji i weryfikacji racji dostatecznych w kontekście zachodzących w otaczającym świecie zjawisk i procesów.

Samą kategorię totalności (wszystkości, całości) ujmuję w nawiązaniu do jej ujęcia stosowanego przez dwóch znamienitych filozofów oraz w odniesieniu do ich projektów filozoficznej dekonstrukcji i delegitymizacji logiki „całości i jedności”. Mam tu na myśli Franza Rosenzweiga i Emmanuela Lévinasa. W odautorskim dookreślaniu tej kategorii, jej implikacji i przejawów w świecie życia codziennego wykraczam jednak poza czysto filozoficzne znaczenia tych projektów. Dla tych filozofów roszczenie całości (ółov), które pojawiło się na arenie filozoficznego rozumowania wraz z greckimi przyrodnikami: Talesem, Anaksymenesem, Empedoklesem czy Demokrytem, wyrażało się w pytaniu o arche panton, zgodnie

$14 \mathrm{~W}$ ostatnim czasie idea polisemiczności i jej miejsce we współczesnej myśli pedagogicznej wyeksponowane zostały w numerze tematycznym „Kwartalnika Pedagogicznego” (Filozofia a pedagogika. Polisemiczność źródeł, kontekstów i granic, 2017). 
z którym dążono do tego, aby wyjaśnić sposób bytowania wszystkich rzeczy oraz ich zaistnienie przy pomocy jednej nadrzędnej zasady. W tym znaczeniu roszczenie objęcia wszystkiego myślą pod postacią jednej nadrzędnej zasady przybrało postać kognitywnej totalizacji lub też swoistego gwałtu intelektualnego monizmu, który zapewnia sobie prawomocność istnienia dzięki procedurze redukcji tego, co odmienne/różne/inne w stosunku do formuły „Wszystkości”. „ «Wszystko» - pisze Franz Rosenzweig - oznacza podmiot pierwszego zdania, które zostało wypowiedziane przy jego narodzinach. Teraz przeciw tej Wszystkości, która obejmuje Wszystko jako Jedność, zbuntowała się Jedność zawarta w sobie samej i wymusiła uporem odmarsz Jednostkowości jako pojedynczego człowieka. Wszystko nie może już twierdzić, że jest "Wszystkim»; zatraciło ono swoja jedyność" (Rosenzweig 1998, s. 63).

Światopoglądowa totalność myślenia i działania wyraża się w roszczeniu podporządkowania wszystkiego jakiemuś jednemu nadrzędnemu wyobrażeniu, poza którym nie ma miejsca na samostanowiące lub równorzędne istnienie innych wyobrażeń świata ludzkich spraw oraz towarzyszących mu znaczeń i rang. Totalność myślenia i działania z założenia znosi potrzebę intersubiektywności w podmiotowej przestrzeni styczności, ponieważ znosi sam dyskurs i potrzebę wymiany określonych punktów widzenia. Totalność w ogóle nie szuka porozumienia, ustępstw, nie zakłada też potrzeby samoograniczenia czy weryfikacji, rewizji lub autokorekty swych własnych nastawień i racji myślenia oraz działania. Totalność zawsze ma charakter zaborczości i ekspansji. Podstawowym skryptem i zarazem regułą totalności myślenia oraz działania jest to, co można określić mianem neutralizacji poddania próbie wchłonięcia, marginalizacji, wykluczenia lub eliminacji. W wieku XX odnotować można, jak się wydaje, trzy typy pragmatycznej operacjonalizacji totalności myślenia i działania w przestrzeni społeczno-kulturowej: totalitarne ideologie, fundamentalizm religijny oraz skrajne ruchy szowinistyczne, promujące rasizm, nacjonalizm czy ksenofobię.

Obstrukcyjnym zagrożeniem dla etosów pluralizacji, demokratyzacji i upodmiotowienia z punktu widzenia tytułowego problemu są co najmniej trzy nieuprawnione - zazwyczaj utrwalane na zasadzie wiedzy milczącej jako nieartykułowane wprost - przedzałożenia, podtrzymywane na mocy roszczenia totalności myślenia i działania. I tak:

1. Etos pluralizacji podlega obstrukcji lub jest dezawuowany na mocy przedzałożenia co do istnienia jakiejś jednej ortodoksyjnej i obiektywnej narracji światopoglądowej, która poddaje się intersubiektywnej afirmacji. Oznacza to, że każda formacja intelektualna pretendująca do miana myśli pedagogicznej, która nie wpisuje się w prawowierność tejże narracji lub jednoznacznie się od niej odróżnia, poddana zostaje roszczeniu totalności, wyrażonemu w skrypcie neutralizacji w przestrzeni dyskursu (wchłonięcia, marginalizacji, wykluczenia lub eliminacji). 
2. Etos demokratyzacji podlega obstrukcji lub jest dezawuowany na mocy przedzałożenia, co do istnienia jakiejś konwergencyjnej ${ }^{15} \mathrm{i}$ w pełni uniwersalnej drogi badawczej oraz samego wyniku badawczego ${ }^{16}$. Oznacza to, że każda formacja intelektualna pretendująca do miana myśli pedagogicznej, która sięga do innych tradycji metodologicznych, a co za tym idzie, w swej optyce problematyzowania przedmiotu badań otwiera się na inny wynik i konkluzje poddające w wątpliwość powszechną obowiązywalność aksjomatów „wiedzy normalnej" (por. Kuhn 2009), spotyka się zarazem z roszczeniem neutralizacji (wchłonięcia, marginalizacji, wykluczenia lub eliminacji).

3. Etos upodmiotowienia podlega obstrukcji lub jest dezawuowany na mocy przedzałożenia, co do możliwości istnienia dyspozycji nieomylnego, bezstronnego i obiektywnego podmiotu poznania, czyli neguje się tu rolę i znaczenie ludzkiej subiektywności lub traktuje się ją nie tyle jako coś, co należy racjonalizować i rozjaśniać, ile wypierać do „szarej sfery” wiedzy milczącej.

\section{Kryterialność orzekania o granicach dyskursywności światopoglądowej współczesnej myśli pedagogicznej}

Polisemiczność epistemologiczno-metodologiczna nie oznacza jednak całkowitej dowolności lub niemożności ustalania obowiązujących kryteriów szacowania naukowej wartości myśli pedagogicznej. Faktem jest, że poszczególne dyskursy w warstwie swej przedzałożeniowości światopoglądowej często są nieporównywalne z punktu widzenia przyjmowanych założeń, preferowanych wzorców aksjologiczno-normatywnych czy też teleologicznego horyzontu - doraźnego i operacyjnego lub odległego i strategicznego - odziaływań pedagogicznych, stanowiąc tym samym odmienne optyki postrzegania i rozpatrywania przedmiotu swojego zainteresowania. Tym niemniej można wskazać dwojakiego co najmniej rodzaju, niebudzące wątpliwości, miary kryteriów naukowego i teoriotwórczego szacowania wartości określonej myśli pedagogicznej. W obu przypadkach odnoszą się one do

15 Odwołując się do pojęcia konwergencyjności (a w rozdziale pierwszym - dywergencyjności) nawiązuję do znaczeń, jakie Józef Kozielecki przypisywał tym kwestiom (Kozielecki, 2002, s. 92-93).

16 Do tak artykułowanego przedzałożenia, w powiązaniu z pierwszym i trzecim przedzałożeniem, odniosłem się również $\mathrm{w}$ innym miejscu, $\mathrm{z}$ innej perspektywy i na inny sposób, w formule „podstawowych typów redukcjonizmu nastawień badawczych”. Spośród siedmiu wyróżnionych tam analitycznie typów redukcjonizmów epistemologiczno-metodologicznych, pięć w sposób ścisły można powiązać z tą kwestią: „redukcjonizm zdolności autonomicznego i adekwatnego rozumowania w obliczu środowiskowo mainstreamowych presji”, „redukcjonizm niedookreśloności i stopniowalności granic otwartości wyobraźni teoretycznej”, „redukcjonizm określoności i rozpoznawalności granic tego, co warunkujące i uwarunkowane”, „redukcjonizm dystansu względem własnych, utrwalonych jednostkowo lub środowiskowo pewników i oczywistości" oraz „redukcjonizm sensotwórczości nieeksponowanych lub skrywanych akcydensów doświadczenia świata życia codziennego" (Gara 2017, s. 162-164). 
kwestii intersubiektywnego statusu badacza jako uczestnika międzypodmiotowej wymiany myśli, uwarunkowanej uznaniem wspólnego horyzontu doświadczenia. Owa intersubiektywność ocen naukowej wartości i adekwatności myśli pedagogicznej możliwa lub zagwarantowana jest poprzez odniesienie się do: 1) kryterium koncepcyjnej, kategorialnej i warsztatowej koherentności określonej myśli oraz 2) kryterium kompatybilności z kulturowo-społecznymi wymogami czy standardami, przywoływanymi w tym miejscu pod postacią dziejowych zdobyczy i stabilizujących osiągnięć jako rudymentów kondycji współczesnego świata Zachodu (tzn. pluralizacji, demokratyzacji, upodmiotowienia).

Pierwsze kryterium można określić mianem wewnątrzkoncepcyjnego, co wbrew pozorom wcale nie oznacza, że jest ono całkowicie subiektywne, a drugie - mianem zewnątrzkoncepcyjnego, co z kolei wcale nie oznacza, że jest ono w zupełności obiektywne. I choć oba kryteria są istotne z punktu widzenia oceny naukowej wartości określonej myśli, to jednak drugie kryterium jest bezpośrednio związane $\mathrm{z}$ podejmowanym $\mathrm{w}$ tym miejscu tytułowym problemem granic dyskursywności światopoglądowej współczesnej myśli pedagogicznej, w takim znaczeniu, w jakim mówimy tutaj o tym, co jest współczesne.

Intersubiektywny wymiar kryterium wewnątrzkoncepcyjnej koherentności określany jest dzisiaj zgodnie z uznanymi standardami odróżniania od siebie myśli odznaczającej się warsztatem naukowym od tej pozbawionej takiego warsztatu. Chodzi tu zatem o takie miary naukowości, jak koncepcyjna spójność i logiczność wywodu, ustrukturyzowanie myśli i jej pojęciowa odpowiedniość czy łączność z tradycją teoretyczną, w obrębie której plasuje się dana myśl, stanowiąc jej kontynuację lub rewizję.

Z kolei intersubiektywny wymiar kryterium zewnętrznej kompatybilności określany jest poczuciem przynależności do tego samego świata kulturowo-społecznego, który warunkuje określoną praxis, przynależną jej historyczną świadomość człowieka oraz właściwą mu strukturę doświadczeń. Mowa tu zatem o egzystencjalnym współdzieleniu tego samego historyczno-kulturowo-społecznego czasu i miejsca, które warunkują podmiot doświadczenia poprzez lokowanie się w obrębie danego okresu historycznego, kręgu kulturowego, czy też w ramach tych samych systemowych i strukturalnych form organizacji życia społecznego. Kryterium to mówi o wspólnym świecie życia, który choć w różnym stopniu i z różnym natężeniem wpływa na indywidualne doświadczenie człowieka, to jednak w sposób określony dziejowo warunkuje też nieredukowalne ramy doświadczenia współczesnych ludzi jako podmiotów o określonej tożsamości historycznej, kulturowej, społecznej czy pokoleniowej. 


\section{Bibliografia}

Barbaras R. (2001). Merleau-Ponty and Nature. „Research in Phenomenology”, t. 31, nr 1, s. 22-38.

Benner D. (2015). Pedagogika ogólna. Wprowadzenie do myślenia i działania pedagogicznego $w$ ujecciu systematycznym i historyczno-problemowym, tłum. D. Stępkowski. Warszawa: Wydawnictwo UKSW.

Blandzi S., Przanowska M. (red.). (2017). Filozofia a pedagogika. Polisemiczność źródeł, kontekstów i granic. „Kwartalnik Pedagogiczny”, nr 1 (243).

Gara (2017). Fenomen nieredukowalności teorii i praktyki pedagogicznej. W: Dudzikowa M., Juszczyk S. (red.). Pułapki epistemologiczne i metodologiczne w badaniach nad edukacją. Jak sobie z nimi radzić. Wykłady Profesorów wygłoszone na XXX Letniej Szkole Młodych Pedagogów przy KNP PAN (Wisła 2016). Warszawa: Wydawnictwo Uniwersytetu Śląskiego.

Gara J. (2016). Egzystencjalne doświadczenie aporii sensu swojskości i zadomowienia $w$ świecie życia codziennego. W: Melosik Z., Szymański M. J. (red.). Tożsamość w warunkach zmiany społecznej. Warszawa: Wydawnictwo Akademii Pedagogiki Specjalnej.

Gara J. (2018). Granice dyskursywności światopoglądowej współczesnej myśli pedagogicznej. „Przegląd Pedagogiczny”, nr 2, s. 1-34 (złożony do druku).

Górniewicz J. (2001). Kategorie pedagogiczne. Olsztyn: Wydawnictwo Uniwersytetu Warmińsko-Mazurskiego.

Hejnicka-Bezwińska T. (2008). Pedagogika ogólna. Warszawa: Wydawnictwo Akademickie i Profesjonalne.

Kozielecki J. (2002). Transgresja i kultura. Warszawa: Wydawnictwo Akademickie "Żak”.

Merleau-Ponty M. (1976a). Obecni w słowie, tłum. J. Skoczylas. W: Proza świata. Eseje o mowie. Warszawa: Czytelnik.

Merleau-Ponty M. (1976b). Postrzeganie, ekspresja, sztuka, tłum. E. Bieńkowska. W: tenże. Proza świata. Eseje o mowie. Warszawa: Czytelnik.

Ortega y Gasset J. (2008). Medytacje o „Don Kichocie”, tłum. J. Wojcieszak. Warszawa: Warszawskie Wydawnictwo Literackie MUZA SA.

Rosenzweig F. (1998). Gwiazda Zbawienia, tłum. T. Gadacz. Kraków: Znak.

Schulz A. (2016). Szkice z pedagogiki ogólnej. Toruń: Wydawnictwo Adam Marszałek.

Śleziński K (2016). Aretologiczne podstawy pedagogiki. Kraków-Cieszyn: Wydawnictwo „scriptum”.

Śliwerski B. (2009). Współczesna myśl pedagogiczna. Znaczenia, klasyfikacje, badania. Kraków: Wydawnictwo „Impuls”. 


\title{
BOUNDARIES OF WORLDVIEW DISCURSIVITY IN THE CONTEMPORARY PEDAGOGICAL THOUGHT
}

\begin{abstract}
The point of reference for the problem outlined in the title are the three inseparable ideas defining the condition of the present and its praxis. They can be described, in general terms, as the ethe of polysemy and cultural pluralism, of democracy and social transparency, and finally of human rights and the empowerment of the individual. These ethe are taken, for the purpose of this work, as defining the boundaries of pedagogical thought as far as it aspires to be considered truly contemporary. Describing some school of thought as contemporary from the point of view of boundaries of its worldview discursivity requires distinguishing two basic ways of understanding what contemporary means. The specific nature of pedagogical thought as one of the cognitive perspectives of general pedagogy is considered in this context, and formal criteria for assessing scientific value of contemporary pedagogical thought are formulated with the above assumptions in mind.
\end{abstract}

Key words: pedagogical theory, general pedagogy, pedagogical thought, phenomenological analysis, epistemological and methodological polysemy.

Jarosław Gara - dr hab., prof. nadzwyczajny Akademii Pedagogiki Specjalnej. Jest kierownikiem Zakładu Pedagogiki Ogólnej i Teorii Wychowania. Wybrane monografie: Pedagogiczne implikacje filozofii dialogu (2008); Od filozoficznych podstaw wychowania do ejdetycznej filozofii wychowania (2009). Adres do korespondencji: APS, ul. Szczęśliwicka 40, o2-353 Warszawa; tel. 2258936 oo, wew. 3440. Adres e-mailowy: jgara@aps.edu.pl. 